\title{
Tworzenie macierzy sztywności i macierzy mas dla zadanych częstotliwości i postaci drgań własnych układu za pomocą algorytmów genetycznych
}

\begin{abstract}
Wyznaczanie charakterystyk sztywnościowych i masowych dla zadanych częstotliwości drgań własnych i postaci drgań własnych projektowanego uktadu jest nadwymiarowym, nieliniowym zadaniem optymalizacyjnym. W artykule, do rozwiqzania zadania, zastosowano metodę algorytmów genetycznych.
\end{abstract}

\section{Wprowadzenie}

Konstrukcje nośne pojazdów są złożonymi, wielowymiarowymi układami, które są opisywane w analitycznych badaniach dynamicznych dyskretnymi modelami o wielu stopniach swobody. Celem analizy dynamicznej modelu układu reprezentowanego macierzą mas i macierzą sztywności jest wyznaczenie jego charakterystyk własnych w postaci częstotliwości drgań własnych i odpowiadającym im postaciom drgań własnych. Tak realizowane zadanie określono jako zadanie wprost, tak zwane proste zagadnienie własne.

Zaprojektowanie konstrukcji o zadanych charakterystykach własnych jako zadanie wprost jest czasochłonnym i pracochłonnym iteracyjnym procesem, nie gwarantującym uzyskania celu (jako metoda prób i błędów).

Jeśli założy się, że układ reprezentowany jest charakterystykami własnymi w postaci częstotliwości drgań własnych i odpowiadającym im postaci drgań własnych, a celem jest wyznaczenie macierzy sztywności i macierzy mas modelu projektowanego układu, to tak postawione zadanie nazwano zadaniem odwrotnym, tak zwane odwrotne zagadnienie własne.

Istotą zastosowania odwrotnego zagadnienia własnego jest to, że fizyczne parametry układu są wyznaczane dla przyjętych charakterystyk dynamicznych. O ile rozwiązywanie zadania wprost jest postępowaniem powszechnie stosowanym oraz istnieją sprawdzone procedury numeryczne $\mathrm{w}$ tym zakresie, o tyle rozwiązywanie zadania odwrotnego jest $\mathrm{w}$ fazie intensywnych badań $[2,5]$.

$\mathrm{Z}$ odwrotnym zagadnieniem własnym związane są dwa podstawowe problemy: teoretyczny, związany $z$ określeniem warunków koniecznych i wystarczających istnienia rozwiązania oraz numeryczny, dotyczacy tworzenia odpowiednich procedur numerycznych. W zależności od zastosowania, odwrotne zagadnienie własne przybiera różną postać, jednak jego rozwiązanie winno spełniać więzy dotyczące charakterystyk własnych oraz więzy dotyczące struktury wyznaczanych macierzy projektowanego układu.
Przedstawione zagadnienie określono jako strukturalne, odwrotne zagadnienie własne, które zapisano w postaci:

Zadany jest zbiór $\left\{\lambda_{1, \ldots,}, \lambda_{n}\right\} \in \mathfrak{R}$. Znaleźć macierz $\mathbf{X} \in \boldsymbol{\aleph}$ taka, ze $\sigma(\mathbf{X})=\left\{\lambda_{1}, \ldots, \lambda_{n}\right\}$, gdzie $\Re$ jest ciatem liczb rzeczywistych, $\aleph$ jest podprzestrzeniq macierzyo przyjętej strukturze $w \mathfrak{R}^{n}$, $\sigma$ jest operatorem znajdowania wartości własnych macierzy.

Przykładowo, dla łańcucha szeregowo połączonych mas macierz $\mathfrak{\aleph}$ jest macierzą Jacobiego. Równanie ruchu takiego układu ma postać:

$$
\mathbf{M} \frac{d^{2} \mathbf{u}}{d t}=\mathbf{K u}
$$

gdzie:

u - jest wektorem przemieszczeń:

$$
\mathbf{u}=\left[\begin{array}{lll}
u_{1} & \ldots & u_{n}
\end{array}\right]^{T}
$$

$\mathbf{M}$ - jest macierzą diagonalną mas:

$$
\mathbf{M}=\operatorname{diag}\left(m_{1}, \ldots, m_{n}\right)
$$

K - jest macierzą sztywności w postaci macierzy Jacobiego:

$$
\mathbf{K}=\left[\begin{array}{ccccc}
-\left(k_{1}+k_{2}\right) & k_{2} & 0 & \ldots & 0 \\
k_{2} & -\left(k_{2}+k_{3}\right) & k_{3} & \ldots & 0 \\
0 & k_{3} & -\left(k_{3}+k_{4}\right) \ldots & 0 \\
\ldots & \ldots & \ldots & \ldots & k_{n} \\
0 & 0 & 0 & k_{n} & -k_{n}
\end{array}\right]
$$

Przyjmując rozwiązanie dla przemieszczeń w postaci $\mathbf{u}(t)=e^{i \omega t} \mathbf{x}$, uzyskano równanie drgań własnych układu

$$
\mathbf{K x}=-\omega^{2} \mathbf{M} \mathbf{x}
$$


Definiując macierz $\mathbf{X}=\mathbf{M}^{\frac{1}{2}} \mathbf{K} \mathbf{M}^{-1} \quad$ oraz podstawiając $\lambda=-\omega^{2}$ opisano zadanie własne $\mathrm{w}$ postaci

$$
\mathbf{X x}=\lambda \mathbf{x}
$$

Równanie (6) umożliwia wyznaczenie częstotliwości drgań własnych i postaci drgań własnych dla znanych wartości $m_{i}$ oraz $k_{k}$. Zagadnienie odwrotne związane jest $\mathrm{z}$ wyznaczeniem wartości takich jak $\frac{-k_{i}-k_{i+1}}{m_{i}}$ oraz $\frac{k_{i+1}}{\sqrt{m_{i} m_{i+1}}}$ dla przyjętych wartości własnych [2].

W przypadku przyjęcia macierzy mas i macierzy sztywności o dowolnej strukturze, rozwiązanie odwrotnego zagadnienia własnego wymaga rozwiązania nieliniowego zadania optymalizacyjnego. Problemy dotyczące rozwiązywania odwrotnego zagadnienia własnego dla układów drgających przedstawiono w [5]. Problem rozwiązania odwrotnego zagadnienia własnego w drganiach układu modelowanego za pomocą metody elementów skończonych, przy zastosowaniu macierzy Jacobiego przedstawiono w [4], a problem tworzenia macierzy mas i macierzy sztywności modelu układu dla zadanych charakterystyk spektralnych, przy zastosowaniu średniokwadratowej metody optymalizacyjnej przedstawiono w [7].

Większość klasycznych metod optymalizacji stosowanych $\mathrm{w}$ procedurach identyfikacji parametrów modelu realizuje strategię przechodzenia $\mathrm{z}$ punktu do punktu, co prowadzi często do znalezienia rozwiązania w postaci optimum lokalnego. Poza tym, wymagane są zwykle dodatkowe informacje dotyczące np. gradientu funkcji celu. W przypadku stosowania optymalizacyjnych metod przeszukiwania badanej przestrzeni rozwiązań wymagane jest przyjęcie odpowiedniego punktu startowego. Tak więc, zastosowanie metod klasycznych do rozwiązania odwrotnego zagadnienia własnego nie jest efektywne.

Uniwersalny charakter metody algorytmów genetycznych powoduje, że jest ona coraz częściej stosowana w zagadnieniach identyfikacji układów drgających. Metodę algorytmów genetycznych zastosowano do optymalizacji pasywnego zawieszenia [1], do syntezy wielo-masowego układu drgającego [3] oraz do parametrycznej identyfikacji struktury nośnej [6].

$\mathrm{W}$ artykule zastosowano metodę algorytmów genetycznych do syntezy macierzy sztywności i macierzy mas modelu układu dla zadanych charakterystyk własnych: częstotliwości drgań własnych i odpowiadających im postaci.

\section{Sformułowanie zadania}

Celem jest wyznaczenie, dla założonych częstotliwości drgań własnych $\Lambda$ oraz macierzy postaci drgań własnych $\Phi$, fizycznie realizowalnych macierzy mas
M i macierzy sztywności $\mathbf{K}$ liniowego, dyskretnego modelu

$$
\mathbf{M} \ddot{\mathbf{q}}(t)+\mathbf{K q}(t)=\mathbf{0}
$$

gdzie:

$$
\begin{aligned}
& \mathbf{M}- \text { dodatnio określona, symetryczna macierz } \\
& \text { mas, } \\
& \mathbf{K}- \text { dodatnio pół-określona, symetryczna ma- } \\
& \text { cierz sztywności, } \\
& \Lambda- \text { macierz częstotliwości własnych, } \\
& \Phi- \text { znormalizowana macierz postaci drgań } \\
& \text { własnych. }
\end{aligned}
$$

Przy przyjęciu $\mathbf{q}(t)=\varphi \sin (\omega t)$ i wykonaniu odpowiednich przekształceń sformułowano symetryczne, uogólnione zagadnienie własne

$$
\mathbf{K} \Phi=\mathbf{M} \Phi \Lambda
$$

Macierze $\mathbf{M}, \mathbf{K}, \Lambda, \Phi$ spełniają warunki ortogonalności

$$
\begin{aligned}
& \boldsymbol{\Phi}^{T} \mathbf{M} \boldsymbol{\Phi}=\mathbf{I} \\
& \boldsymbol{\Phi}^{T} \mathbf{K} \boldsymbol{\Phi}=\boldsymbol{\Lambda}
\end{aligned}
$$

gdzie I jest macierzą jednostkową.

Elementy macierzy mas $\mathbf{M}$ są rzeczywistymi, dodatnimi wartościami. Elementy macierzy sztywności $\mathbf{K}$ spełniają następuiące zależności:

$$
\begin{gathered}
k_{i i}>0, \text { dla } i=1,2, \ldots, n \\
k_{i j}<0, \text { dla } i \neq j \\
\sum_{j=1}^{n} k_{i j} \geq 0 \text {, dla } i, j=1,2, \ldots, n
\end{gathered}
$$

Macierz mas $\mathbf{M}$ oraz macierz sztywności $\mathbf{K}$ wyznaczone na podstawie warunków ortogonalności jako

$$
\begin{gathered}
\mathbf{M}=\boldsymbol{\Phi}^{-T} \boldsymbol{\Phi}^{-1} \\
\mathbf{K}=\boldsymbol{\Phi}^{-T} \boldsymbol{\Lambda} \boldsymbol{\Phi}^{-1}
\end{gathered}
$$

przeważnie nie są fizycznie realizowalne.

W artykule przyjęto, że zadane macierze wartości częstotliwości drgań własnych i postaci drgań własnych będą oznaczane indeksem * (odpowiednio $\Lambda$ * oraz $\left.\Phi^{*}\right)$, a wyznaczone macierze wartości częstotliwości drgań własnych i postaci drgań własnych będą oznaczane bez indeksu (odpowiednio $\Lambda$ oraz $\Phi$ ).

W celu wyznaczenia fizycznie realizowalnych macierzy mas $\mathbf{M}$ oraz macierzy sztywności $\mathbf{K}$ sformułowano zadanie optymalizacyjne:

Dla zadanych wartości własnych $\Lambda^{*}=\left\{\lambda_{1}{ }^{*}, \ldots, \lambda_{n}{ }^{*}\right\} i$ odpowiadajacych im wektorów wlasnych $\Phi^{*}=\left\{\varphi_{1}{ }^{*}, \ldots, \varphi_{n}^{*}\right\}$ wyznaczyć fizycznie realizowalne macierze mas $\mathbf{M}$ i sztywności $\mathbf{K}$ przy przyjęciu funkcji celu zależnych od $\Lambda^{*}, \Phi^{*}, \Lambda$ oraz $\Phi$.

Do rozwiązania zadania optymalizacyjnego zastosowano metodę algorytmów genetycznych. 
Zadanie rozwiązano $\mathrm{w}$ dwóch etapach:

"A" Jako proste zagadnienie własne.

Dla przyjętej struktury przyjęto macierz mas $\mathbf{M}$ i macierz sztywności $\mathbf{K}$. Wyznaczono macierz częstotliwości drgań własnych $\Lambda$ oraz macierz postaci drgań własnych $\Phi$, wykorzystując odpowiednie procedury numeryczne [8].

"B" Jako odwrotne zagadnienie własne.

Dla przyjętej struktury przyjęto macierz częstotliwości drgań własnych $\Lambda^{*}$ oraz macierz postaci drgań własnych $\Phi^{*}$ uzyskane jako wynikowe w etapie "A".

\section{Opis algorytmów genetycznych}

Algorytmy genetyczne są algorytmami poszukiwania rozwiązania opartymi na mechanizmach doboru naturalnego oraz dziedziczności. Łączą w sobie ewolucyjną zasadę przeżycia jednostek najlepiej przystosowanych, $\mathrm{z}$ systematyczną, choć zrandomizowaną wymianą informacji. Algorytm genetyczny wykonuje wielokierunkowe przeszukiwanie przez przekształcanie populacji potencjalnych rozwiązań i prowadzi do zbierania informacji genetycznej i jej wymiany między tymi kierunkami. Populacja podlega symulowanej ewolucji: w każdym następnym pokoleniu stosunkowo „dobre" rozwiązania reprodukują się, a stosunkowo ,złe” wymieraja. Algorytmy genetyczne korzystają z określeń zapożyczonych z genetyki. Parametry, od których zależy rozwiązanie określa się jako geny, a ich uporządkowany ciąg chromosomem. Zbiór osobników określanych mianem chromosomów nazywa się populacją. Dla oceny chromosomu wprowadzona jest funkcja przystosowania, reprezentująca tak zwane środowisko.

Realizacja algorytmu genetycznego przebiega według następującego schematu:

[I] generowana jest początkowa populacja,

[II] każdemu osobnikowi przyporządkowana zostaje wartość funkcji przystosowania,

[III] osobniki o lepszym przystosowaniu są selekcjonowane do dalszego przetwarzania,

[IV] wybrane według odpowiedniego klucza pary osobników z puli rodzicielskiej są poddane operacji krzyżowania tworzącej potomków,

[V] osobniki nowej populacji są poddawane mutacji,

[VI] proces jest kontynuowany od punktu [II] aż do uzyskania zadowalającego rozwiązania.

Od tradycyjnych metod optymalizacyjnych algorytmy genetyczne różnią się tym, że:

- nie przetwarzają bezpośrednio parametrów zadania lecz ich zakodowaną postać
- prowadzą przeszukiwanie wychodząc nie z pojedynczego punktu lecz z pewnej ich populacji

- korzystają tylko z funkcji przystosowania, nie zaś $z$ jej pochodnych lub innych pomocniczych informacji

- stosują probabilistyczne, a nie deterministyczne reguły wyboru.

Podstawowym elementem realizacji algorytmów genetycznych jest funkcja przystosowania. Stanowi ona miare przystosowania danego osobnika $\mathrm{w}$ populacji. Funkcja ta jest niezwykle istotna, gdyż pozwala ocenić stopień przystosowania poszczególnych osobników populacji i na tej podstawie wybrać osobniki najlepiej przystosowane, zgodnie z ewolucyjną zasadą przetrwania najlepiej przystosowanych.

$\mathrm{W}$ artykule sformułowano następujące zadanie badawcze:

Dla zadanych wartości własnych $\Lambda^{*}=\left\{\lambda_{1}{ }^{*}, \ldots, \lambda_{5}{ }^{*}\right\} i$ odpowiadajacych im wektorów wtasnych $\Phi{ }^{*}=\left\{\varphi^{*}, \ldots, \varphi_{5}{ }^{*}\right\}$ wyznaczyć fizycznie realizowalne macierze mas $\mathbf{M}$ i sztywności $\mathbf{K}$ przy przyjęciu, że w funkcji celu będacej funkcja przystosowania uwzględniono różnice wektorów częstotliwości własnych $\left\|\boldsymbol{\Lambda}^{*}-\boldsymbol{\Lambda}\right\|$, różnicę wektorów postaci drgań wtasnych $\| \boldsymbol{\Phi}^{*}$ - $\boldsymbol{\Phi} \|$ oraz tzw. wspótczynnik MAC (Modal Assurance Criterion).

Współczynnik $M A C$ dla dwóch wektorów modalnych jest zdefiniowany za pomocą wzoru:

$$
\operatorname{MAC}\left(\varphi_{i}^{*}, \varphi_{i}\right)=\frac{\left|\varphi_{i}^{*} T \varphi_{i}\right|^{2}}{\left(\varphi_{i}^{*} \varphi_{i}^{*}\right)\left(\varphi_{i}^{T} \varphi_{i}\right)}
$$

Współczynnik $M A C$ jest współczynnikiem korelacji zdefiniowanych wektorów własnych. Jeżeli współczynnik $M A C$ ma wartość 1 , to porównywane wektory są jednakowe.

Funkcja przystosowania składa się z dwóch elementów, pierwszy dotyczy częstotliwości drgań własnych $J_{\omega}$

$$
J_{\omega}=\sum_{i=1}^{r} W_{\omega i}\left(\frac{\omega_{i}^{*}-\omega_{i}}{\omega_{i}^{*}}\right)^{2}
$$

a drugi postaci drgań własnych modelu układu $J \Phi_{1}$ oraz $J \Phi_{2}$

$$
\begin{gathered}
J_{\Phi 1}=\sum_{i=1}^{r} W_{\Phi i}\left(\varphi_{i}^{*}-\varphi_{i}\right)^{T}\left(\varphi_{i}^{*}-\varphi_{i}\right) \\
J_{\Phi 2}=\sum_{i=1}^{r} W_{\Phi i}\left(1-\operatorname{MAC}\left(\varphi_{i}^{*}, \varphi_{i}\right)\right)
\end{gathered}
$$

W pracy geny są liczbami rzeczywistymi, zmiennoprzecinkowymi wartościami mas i sztywności elementów sprężystych projektowanego układu. 
Chromosom stanowi uporządkowany, szesnastoelementowy zbiór genów w postaci: $c h=\left[\begin{array}{lll}m_{1} & m_{2} & m_{3}\end{array}\right.$ $\left.m_{4} m_{5} k_{1} k_{2} k_{3} k_{4} k_{5} k_{6} k_{7} k_{8} k_{9} k_{10} k_{11}\right]$.

Celem jest znalezienie chromosomu minimalizującego funkcję przystosowania, która została przyięta w dwóch postaciach $J_{\mathrm{A}}$ i $J_{\mathrm{B}}$ :

$$
\begin{aligned}
& J_{A}=J_{\omega}+J_{\Phi 1} \\
& J_{B}=J_{\omega}+J_{\Phi 2}
\end{aligned}
$$

\section{Przykład obliczeniowy}

Model układu, dla którego przeprowadzono wstępną analizę w zakresie oceny zastosowania algorytmów genetycznych do rozwiązywania odwrotnego zagadnienia własnego, przedstawiono na rysunku 1.

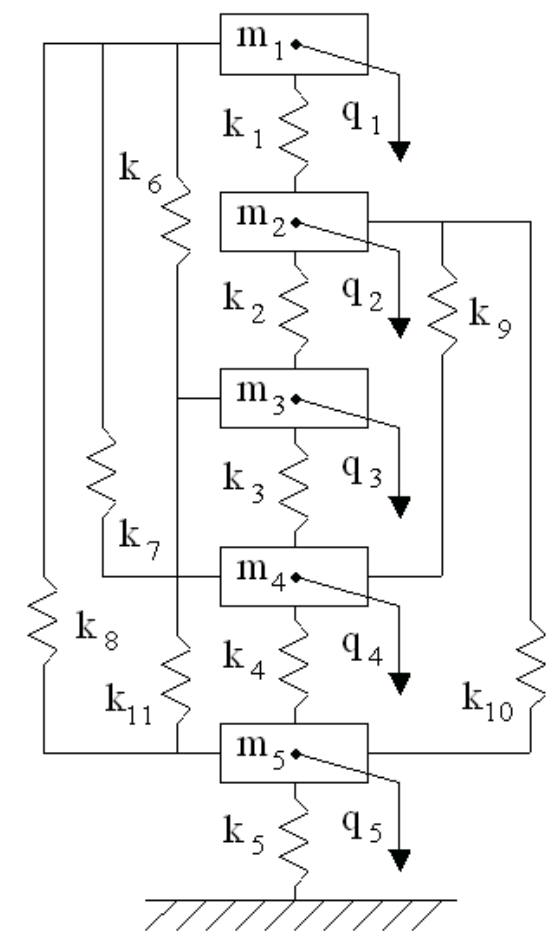

Rys. 1. Model układu o pięciu stopniach swobody opisany równaniem (7)

Model opisano pięciowymiarowym wektorem współrzędnych uogólnionych $\mathbf{q}(t)$

$$
\mathbf{q}(t)=\left[q_{1}(t) q_{2}(t) q_{3}(t) q_{4}(t) q_{5}(t)\right]^{T}
$$

Macierz mas M modelu ma postać:

$$
\mathbf{M}=\left[\begin{array}{ccccc}
m_{1} & 0 & 0 & 0 & 0 \\
0 & m_{2} & 0 & 0 & 0 \\
0 & 0 & m_{3} & 0 & 0 \\
0 & 0 & 0 & m_{4} & 0 \\
0 & 0 & 0 & 0 & m_{5}
\end{array}\right]
$$

Macierz sztywności K modelu ma postać:

$$
\mathbf{K}=\left[\begin{array}{ccccc}
K_{1} & -k_{1} & -k_{6} & -k_{7} & -k_{8} \\
& K_{2} & -k_{2} & -k_{9} & -k_{10} \\
& & K_{3} & -k_{3} & -k_{11} \\
& \text { sym. } & & K_{4} & -k_{4} \\
& & & & K_{5}
\end{array}\right]
$$

gdzie:

$$
\begin{aligned}
& K_{1}=k_{1}+k_{6}+k_{7}+k_{8} \\
& K_{2}=k_{1}+k_{2}+k_{9}+k_{10} \\
& K_{3}=k_{2}+k_{3}+k_{6}+k_{11} \\
& K_{4}=k_{3}+k_{4}+k_{7}+k_{9} \\
& K_{5}=k_{4}+k_{5}+k_{8}+k_{10}+k_{11}
\end{aligned}
$$

\section{ETAP ,A”}

Po przeprowadzeniu wstępnych obliczeń numerycznych przyjęto następujące wartości stałych charakteryzujących właściwości masowe i sztywnościowe modelu:

$$
\begin{aligned}
& m_{1}{ }^{*}=m_{2}{ }^{*}=m_{3}{ }^{*}=10[\mathrm{~kg}] \\
& m_{4}{ }^{*}=12[\mathrm{~kg}] \\
& m_{5}{ }^{*}=15[\mathrm{~kg}] \\
& k_{1}{ }^{*}=k_{2}{ }^{*}=k_{3}{ }^{*}=600[\mathrm{~N} / \mathrm{m}] \\
& k_{4}{ }^{*}=k_{5}{ }^{*}=800[\mathrm{~N} / \mathrm{m}] \\
& k_{6}{ }^{*}=k_{7}{ }^{*}=k_{8}{ }^{*}=k_{9}{ }^{*}=k_{10}{ }^{*}=k_{11}{ }^{*}=200[\mathrm{~N} / \mathrm{m}]
\end{aligned}
$$

Macierz mas $\mathbf{M}^{*}$ i macierz sztywności $\mathbf{K}^{*}$ dla przyjętych wartości mają postać:

$$
\begin{aligned}
& \mathbf{M}^{*}=\left[\begin{array}{ccccc}
10 & 0 & 0 & 0 & 0 \\
0 & 10 & 0 & 0 & 0 \\
0 & 0 & 10 & 0 & 0 \\
0 & 0 & 0 & 12 & 0 \\
0 & 0 & 0 & 0 & 15
\end{array}\right][\mathrm{kg}] \\
& \mathbf{K}^{*}=\left[\begin{array}{rrrrr}
1200 & -600 & -200 & -200 & -200 \\
-600 & 1600 & -600 & -200 & -200 \\
-200 & -600 & 1600 & -600 & -200 \\
-200 & -200 & -600 & 1800 & -800 \\
-200 & -200 & -200 & -800 & 2200
\end{array}\right][\mathrm{N} / \mathrm{m}]
\end{aligned}
$$

Dla modelu reprezentowanego macierzą mas $\mathbf{M}^{*} \mathrm{i}$ sztywności $\mathbf{K}^{*}$ zapisano zagadnienie własne (8), po rozwiązaniu którego uzyskano wartości własne, odpowiadające częstotliwościom drgań własnych $\Lambda^{*}$ oraz wektory własne, odpowiadające postaciom drgań własnych $\Phi^{*}$ :

$$
\mathbf{\Lambda}^{*}=\left[\begin{array}{c}
3,19 \\
10,80 \\
12,71 \\
14,37 \\
15,53
\end{array}\right][\mathrm{rad} / \mathrm{s}]
$$




$$
\boldsymbol{\Phi}^{*}=\left[\begin{array}{ccccc}
-0,149 & 0,191 & 0,160 & -0,105 & 0,066 \\
-0,148 & 0,109 & -0,086 & 0,166 & -0,175 \\
-0,145 & -0,020 & -0,200 & -0,015 & 0,195 \\
-0,132 & -0,144 & -0,005 & -0,165 & -0,132 \\
-0,095 & -0,131 & 0,133 & 0,136 & 0,062
\end{array}\right]
$$

\section{ETAP „B”}

Proces rozwiązywania odwrotnego zagadnienia własnego $\mathrm{z}$ zastosowaniem metody algorytmów genetycznych przebiega zgodnie ze schematem przedstawionym w punkcie 3 .

Przyjęto chromosom w postaci:

$c h_{p}=\left\{m_{p 1} m_{p 2} m_{p 3} m_{p 4} m_{p 5} k_{p 1} k_{p 2} k_{p 3} k_{p 4} k_{p 5} k_{p 6} k_{p 7} k_{p 8}\right.$ $\left.k_{p 9} k_{p 10} k_{p 11}\right\}$

gdzie $p$ jest rozmiarem populacji.

Do generowania populacji początkowej wykorzystano generator rozkładu równomiernego, przy przyjęciu odpowiednich przedziałów zmienności wartości genów.

W realizacji algorytmu genetycznego wykorzystano dwie operacje selekcji:

- selekcja według stochastycznego rozkładu (S1) każdemu chromosomowi przypisywany jest odcinek proporcjonalny do wartości odpowiadającej mu funkcji przystosowania, generowane sa punkty linii ze stałym krokiem stanowiące populację początkową,

- selekcja z zastosowaniem ruletki (S2) - powierzchnia koła zostaje podzielona na segmenty przyporządkowywane chromosomom proporcjonalnie do wartości funkcji przystosowania,

oraz dwie operacje krzyżowania:

- krzyżowanie binarne (C1) - generowane jest losowo słowo binarne (ciąg zer i jedynek) o długości chromosomu, poszczególne geny chromosomu potomka pochodzą od chromosomu pierwszego rodzica w przypadku wartości 1 i od drugiego rodzica w przypadku wartości 0 ,

- krzyżowanie arytmetyczne (C2) -potomek jest ważoną sumą algebraiczną chromosomów rodzicielskich.

Prawdopodobieństwo wystąpienia operacji krzyżowania $p_{c}=0,8$, a prawdopodobieństwo wystapienia mutacji $p_{m}=0,1$.

Przyjęto cztery warianty badawcze.

Wariant A1 - funkcja przystosowania $J_{A}$, operacja selekcji S1 oraz operacja krzyżowania $\mathrm{C} 1$.

Wariant A2 - funkcja przystosowania $J_{A}$, operacja selekcji S2 oraz operacja krzyżowania $\mathrm{C} 2$.

Wariant B1 - funkcja przystosowania $J_{B}$, operacja selekcji S1 oraz operacja krzyżowania $\mathrm{C} 1$.
Wariant B2 - funkcja przystosowania $J_{B}$, operacja selekcji S2 oraz operacja krzyżowania $\mathrm{C} 2$.

W celu określenia liczby generacji przeprowadzono wstępne analizy numeryczne, na podstawie których przyjęto dla wariantów A1 oraz A2 każdy po 40 generacji, a dla wariantu B1 oraz B2 każdy po 60 generacji.

Jakość wyników uzyskanych z wykorzystaniem algorytmów genetycznych zależy od rozmiaru populacji i wyniki przedstawiono dla przyjętych przykładowo dwóch wielkości populacji: 500 i 2000. Wyniki przeprowadzonej analizy wpływu wielkości populacji na przebieg zmian minimalnej wartości funkcji przystosowania $\mathrm{w}$ kolejnych generacjach przedstawiono dla wariantu A1 na rysunku 2, dla wariantu A2 na rysun$\mathrm{ku} 3$, dla wariantu B1 na rysunku 4 oraz dla wariantu B2 na rysunku 5.

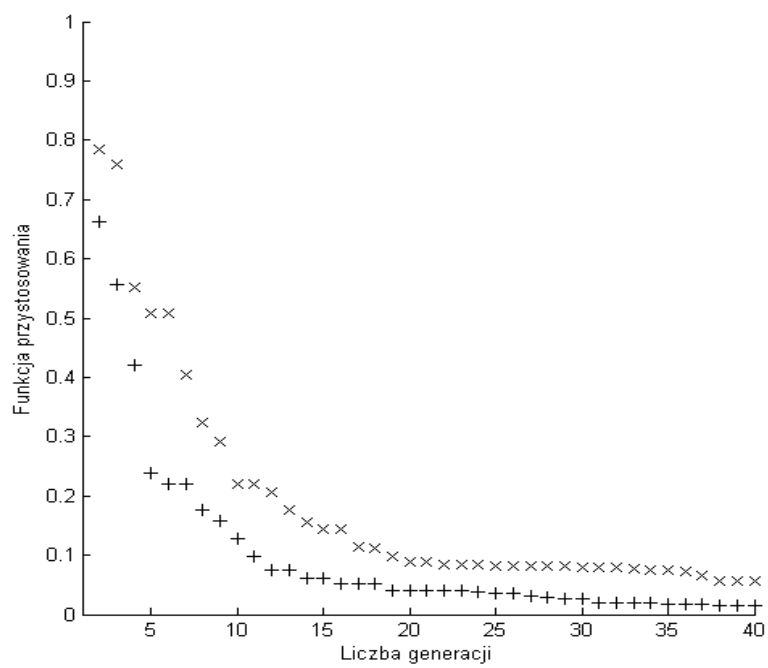

Rys. 2. Przebiegi zmian dla wariantu A1 minimalnych wartości funkcji przystosowania dla kolejnych generacji dla przyjętych wielkości populacji: 500 (oznaczone $\times$ ), 2000 (oznaczone + ).

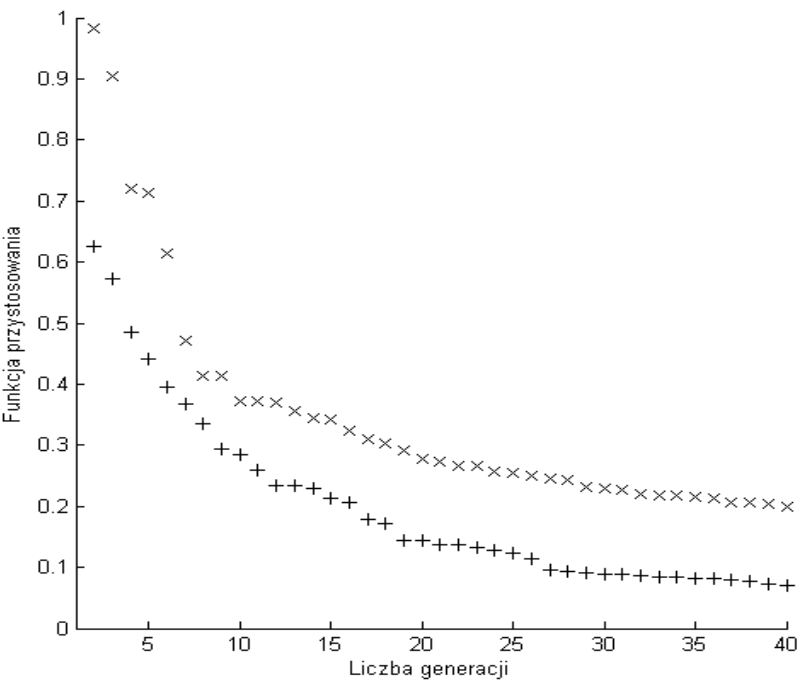

Rys. 3. Przebiegi zmian dla wariantu A2 minimalnych wartości funkcji przystosowania dla kolejnych generacji dla przyjętych wielkości populacji: 500 (oznaczone $\times$ ), 2000 (oznaczone + ). 


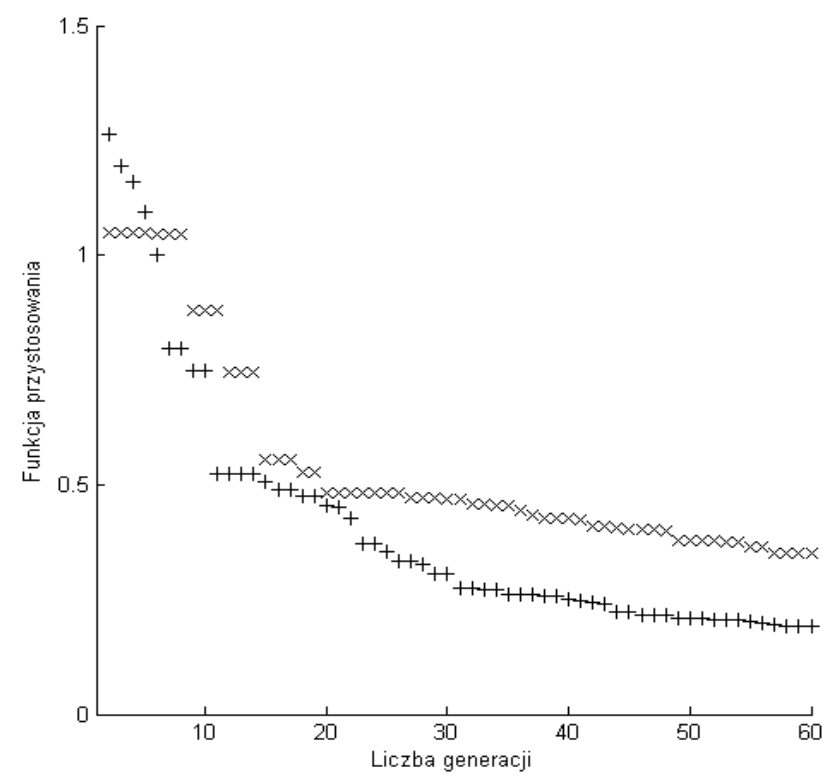

Rys. 4. Przebiegi zmian dla wariantu B1 minimalnych wartości funkcji przystosowania dla kolejnych generacji dla przyjętych wielkości populacji: 500 (oznaczone $\times$ ), 2000 (oznaczone + ).

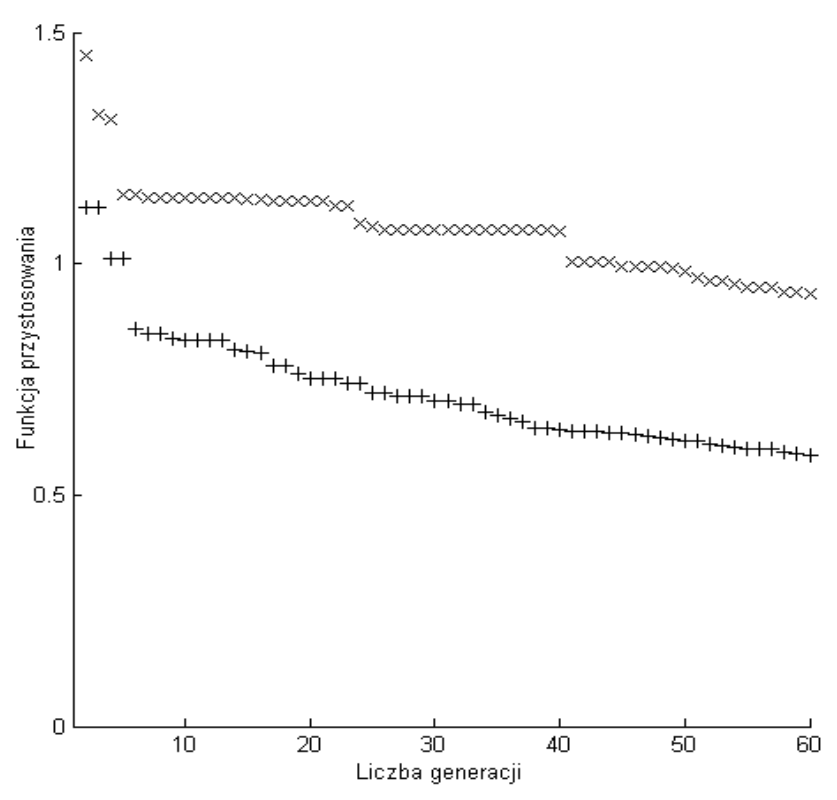

Rys. 5. Przebiegi zmian dla wariantu B2 minimalnych wartości funkcji przystosowania dla kolejnych generacji dla przyjętych wielkości populacji: 500 (oznaczone $\times$ ), 2000 (oznaczone + ).

Do obliczeń przyjęto populację o rozmiarze 2000 osobników jako gwarantującą uzyskanie założonej dokładności. Badania numeryczne przeprowadzono za pomocą systemu [8]. Minimalne wartości funkcji przystosowania dla poszczególnych wariantów przedstawiono poniżej:
$J_{\mathrm{A} 1}=0.0165$
$J_{\mathrm{B} 1}=0.1931$
$J_{\mathrm{A} 2}=0.0708$$$
J_{\mathrm{B} 2}=0.5844
$$

Porównanie uzyskanych wyników może być przeprowadzone dla poszczególnych wariantów. Wariant $J_{\mathrm{A} 1}$ przewyższa wariant $J_{\mathrm{A} 2}$, a wariant $J_{\mathrm{B} 1}$ przewyższa wariant $J_{\mathrm{B} 2}$.
Wyznaczonym, minimalnym wartościom funkcji przystosowania dla poszczególnych wariantów odpowiadaja chromosomy oznaczone $c h_{\mathrm{A} 1}, c h_{\mathrm{A} 2}, c h_{\mathrm{B} 1}$ oraz $c h_{\mathrm{B} 2}$ :

$c h_{A 1}=\left[\begin{array}{c}12,15 \\ 12,42 \\ 12,04 \\ 12,91 \\ 16,79 \\ 753,37 \\ 747,11 \\ 639,88 \\ 876,60 \\ 941,06 \\ 273,64 \\ 185,38 \\ 244,89 \\ 201,42 \\ 303,21 \\ 197,34\end{array}\right] c h_{A 2}=\left[\begin{array}{c}11,92 \\ 10,49 \\ 10,96 \\ 12,54 \\ 14,76 \\ 605,10 \\ 640,69 \\ 599,90 \\ 764,47 \\ 859,19 \\ 321,93 \\ 184,84 \\ 230,32 \\ 259,57 \\ 208,59 \\ 202,97\end{array}\right] c h_{B 1}=\left[\begin{array}{c}13,46 \\ 13,75 \\ 12,33 \\ 10,90 \\ 16,32 \\ 863,65 \\ 835,39 \\ 587,42 \\ 747,35 \\ 998,52 \\ 312,28 \\ 159,27 \\ 253,90 \\ 176,34 \\ 293,12 \\ 194,91\end{array}\right] c h_{B 2}=\left[\begin{array}{c}13,52 \\ 9,54 \\ 13,00 \\ 12,55 \\ 16,66 \\ 301,92 \\ 562,80 \\ 367,74 \\ 659,12 \\ 810,78 \\ 659,92 \\ 127,74 \\ 493,95 \\ 359,24 \\ 526,33 \\ 241,50\end{array}\right]$

W celu przeprowadzenia analizy porównawczej wartości mas dla prostego zadania własnego oraz wartości mas uzyskane jako rozwiązania odwrotnego zadania własnego przedstawiono w tabeli 1, a wartości sztywności dla prostego zadania własnego oraz wartości sztywności uzyskane jako rozwiązania odwrotnego zadania własnego przedstawiono $\mathrm{w}$ tabeli 2 . Błędy wyznaczono według zależności: ((wartość nominalna - wartość obliczona) / wartość nominalna) $\cdot 100 \%$.

Wartości przyjętych funkcji przystosowania zależne są bezpośrednio od wartości częstotliwości drgań własnych oraz wartości postaci drgań własnych (założonych i wyznaczonych). Wpływ przyjętych wariantów obliczeniowych na wielkości, od których zależne są funkcje przystosowania przedstawiono $\mathrm{w}$ tabeli 3 (dla częstotliwości drgań własnych) oraz $\mathrm{w}$ postaci macierzy $\Phi^{*}, \Phi_{\mathrm{A} 1}, \Psi_{\mathrm{A} 1}, \Psi_{\mathrm{A} 2}, \Psi_{\mathrm{B} 1}$ oraz $\Psi_{\mathrm{B} 2}$ (dla postaci drgań własnych).

Zadaną macierz postaci drgań własnych zapisano jako $\Phi$ * a macierz postaci drgań własnych uzyskanych dla wariantu A1 zapisano jako $\Phi_{A 1}$ :

$$
\boldsymbol{\Phi}^{*}=\left[\begin{array}{ccccc}
-0,149 & 0,191 & 0,160 & -0,105 & 0,066 \\
-0,148 & 0,109 & -0,086 & 0,166 & -0,175 \\
-0,145 & -0,020 & -0,200 & -0,015 & 0,195 \\
-0,132 & -0,144 & -0,005 & -0,165 & -0,132 \\
-0,095 & -0,131 & 0,133 & 0,136 & 0,062
\end{array}\right]
$$

$$
\boldsymbol{\Phi}_{A 1}=\left[\begin{array}{ccccc}
-0,137 & 0,171 & 0,139 & -0,105 & 0,057 \\
-0,136 & 0,090 & -0,065 & 0,147 & -0,166 \\
-0,135 & -0,016 & -0,192 & -0,015 & 0,164 \\
-0,121 & -0,155 & -0,005 & -0,152 & -0,122 \\
-0,087 & -0,115 & 0,125 & 0,131 & 0,075
\end{array}\right]
$$


Wartości mas przyjęte dla prostego zadania własnego oraz wartości mas uzyskane jako rozwiazania odwrotnego zadania wlasnego

\begin{tabular}{|c|c|c|c|c|c|c|c|c|c|}
\hline \multirow[b]{2}{*}{$i$} & \multirow{2}{*}{$\begin{array}{c}m_{i}{ }^{*} \\
{[\mathrm{~kg}]}\end{array}$} & \multicolumn{2}{|c|}{ Wariant A1 } & \multicolumn{2}{|c|}{ Wariant A2 } & \multicolumn{2}{|c|}{ Wariant B1 } & \multicolumn{2}{|c|}{ Wariant B2 } \\
\hline & & $\begin{array}{c}m_{i} \\
{[\mathrm{~kg}]}\end{array}$ & błąd [\%] & $\begin{array}{c}m_{i} \\
{[\mathrm{~kg}}\end{array}$ & błąd [\%] & $\begin{array}{c}m_{i} \\
{[\mathrm{~kg}]}\end{array}$ & błąd [\%] & $\begin{array}{c}m_{i} \\
{[\mathrm{~kg}]}\end{array}$ & błąd [\%] \\
\hline 1 & 10,00 & 12,15 & 21.53 & 11,92 & 19.28 & 13,46 & 34,63 & 13,52 & 35.26 \\
\hline 2 & 10,00 & 12,42 & 24,23 & 10,49 & 4,99 & 13,75 & 37,54 & 9,54 & 4,51 \\
\hline 3 & 10,00 & 12,04 & 20,45 & 10,96 & 9,66 & 12,33 & 23,33 & 13,00 & 30,06 \\
\hline 4 & 12,00 & 12,91 & 7,60 & 12,54 & 4,57 & 10,90 & 9,15 & 12,55 & 4,62 \\
\hline 5 & 15,00 & 16,79 & 11,95 & 14,76 & 1,57 & 16,32 & 8,85 & 16,66 & 11,09 \\
\hline
\end{tabular}

Wartości sztywności przyjęte dla prostego zadania własnego oraz wartości sztywności uzyskane jako rozwiazania odwrotnego zadania wlasnego

\begin{tabular}{|c|c|c|c|c|c|c|c|c|c|}
\hline \multirow[b]{2}{*}{$i$} & \multirow{2}{*}{$\begin{array}{c}k_{i}^{*} \\
{[\mathrm{~N} / \mathrm{m}]}\end{array}$} & \multicolumn{2}{|c|}{ Wariant A1 } & \multicolumn{2}{|c|}{ Wariant $\mathrm{A} 2$} & \multicolumn{2}{|c|}{ Wariant B1 } & \multicolumn{2}{|c|}{ Wariant B2 } \\
\hline & & $\begin{array}{c}k_{i} \\
{[\mathrm{~N} / \mathrm{m}]}\end{array}$ & błąd [\%] & $\begin{array}{c}k_{i} \\
{[\mathrm{~N} / \mathrm{m}]}\end{array}$ & błąd [\%] & $\begin{array}{c}k_{i} \\
{[\mathrm{~N} / \mathrm{m}]}\end{array}$ & błąd [\%] & $\begin{array}{c}k_{i} \\
{[\mathrm{~N} / \mathrm{m}]}\end{array}$ & błąd [\%] \\
\hline 1 & 600,00 & 753,37 & 25,56 & 605,10 & 0,85 & 863,65 & 43,94 & 301,92 & 49,67 \\
\hline 2 & 600,00 & 747,11 & 24,51 & 640,69 & 6,78 & 835,39 & 39,23 & 562,80 & 6,19 \\
\hline 3 & 600,00 & 639,88 & 6,64 & 599,90 & 0,01 & 587,42 & 2,09 & 367,74 & 38,70 \\
\hline 4 & 800,00 & 876,60 & 9,57 & 764,47 & 4,44 & 747,35 & 6,58 & 659,12 & 17,60 \\
\hline 5 & 800,00 & 941,06 & 17,63 & 859,19 & 7,39 & 998,52 & 24,81 & 810,78 & 1,34 \\
\hline 6 & 200,00 & 273,64 & 36,82 & 321,93 & 60,96 & 312,28 & 56,14 & 659,92 & 229,96 \\
\hline 7 & 200,00 & 185,38 & 7,30 & 184,84 & 7,57 & 159,27 & 20,36 & 127,74 & 36,12 \\
\hline 8 & 200,00 & 244,89 & 22,44 & 230,32 & 15,16 & 253,90 & 26,95 & 493,95 & 146,97 \\
\hline 9 & 200,00 & 201,42 & 0,71 & 259,57 & 29,78 & 176,34 & 11,82 & 359,24 & 79,62 \\
\hline 10 & 200,00 & 303,21 & 51,60 & 208,59 & 4,29 & 293,12 & 46,56 & 526,33 & 163,16 \\
\hline 11 & 200,00 & 197,34 & 1,32 & 202,97 & 1,48 & 194,91 & 2,54 & 241,50 & 20,75 \\
\hline
\end{tabular}

Porównanie przyjętych częstotliwości drgań własnych układu z wyznaczonymi dla po-

\begin{tabular}{|c|c|c|c|c|c|c|c|c|c|}
\hline \multirow[b]{3}{*}{$i$} & \multirow{3}{*}{$\begin{array}{c}\omega_{i}^{*} \\
{[\mathrm{rad} / \mathrm{s}]}\end{array}$} & & wariantó & A1, & 1 or & & & & ela 3 \\
\hline & & \multicolumn{2}{|c|}{ Wariant A1 } & \multicolumn{2}{|c|}{ Wariant $\mathrm{A} 2$} & \multicolumn{2}{|c|}{ Wariant B1 } & \multicolumn{2}{|c|}{ Wariant B2 } \\
\hline & & $\begin{array}{c}\omega_{i} \\
{[\mathrm{rd} / \mathrm{s}]}\end{array}$ & błąd [\%] & $\begin{array}{c}\omega_{i} \\
{[\mathrm{rad} / \mathrm{s}]}\end{array}$ & błąd [\%] & $\begin{array}{c}\omega_{i} \\
{[\mathrm{rd} / \mathrm{s}]}\end{array}$ & błąd [\%] & $\begin{array}{c}\omega_{i} \\
{[\mathrm{rad} / \mathrm{s}]}\end{array}$ & błąd [\%] \\
\hline 1 & 3,19 & 3,18 & 0,02 & 3,16 & 1,04 & 3,20 & 0,09 & 3,14 & 1,78 \\
\hline 2 & 10,80 & 10,79 & 0,03 & 10,91 & 1,00 & 10,81 & 0,08 & 11,06 & 2,40 \\
\hline 3 & 12,71 & 12,71 & 0,01 & 12,84 & 1,01 & 12,73 & 0,13 & 13,07 & 2,84 \\
\hline 4 & 14,37 & 14,35 & 0,15 & 14,37 & 0,02 & 14,35 & 0,16 & 13,83 & 3,76 \\
\hline 5 & 15,53 & 15,52 & 0,08 & 15,28 & 1,59 & 15,57 & 0,24 & 15,20 & 2,15 \\
\hline
\end{tabular}

Otrzymaną macierz postaci drgań własnych $\Phi_{\mathrm{A} 1}$ porównano graficznie $\mathrm{z}$ macierzą zadanych postaci drgań własnych $\Phi^{*}$ na rysunku 6 , a macierz postaci drgań własnych $\Phi_{\text {в2 }}$ porównano graficznie z macierzą zadanych postaci drgań własnych $\Phi$ "na rysunku $7 . \mathrm{Na}$ osiach odciętych przyjęto wartości współrzędnych wektorów zadanych, a na osiach rzędnych przyjęto wartości współrzędnych wektorów uzyskanych z obliczeń. Linie symetrii, oznaczone kreską przerywana, odpowiadają równości współrzędnych wektorów postaci drgań własnych zadanych oraz uzyskanych.

Rys. 6. Graficzna interpretacja podobieństwa wektorów postaci drgań własnych założonych i uzyskanych dla wariantu A1.

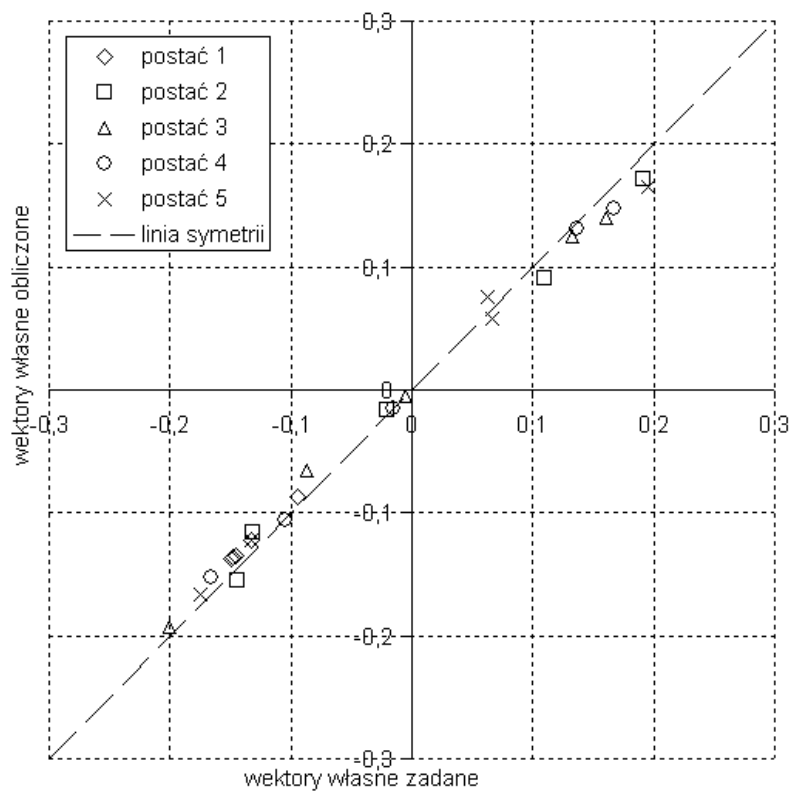




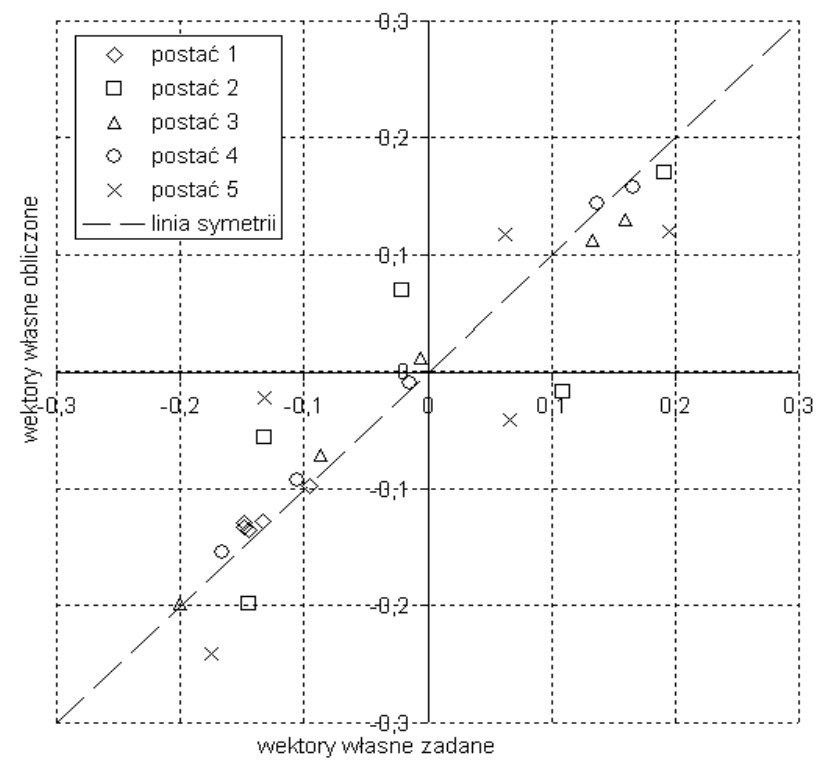

Rys. 7. Graficzna interpretacja podobieństwa wektorów postaci drgań własnych założonych i uzyskanych dla wariantu B2

Jako algebraiczną miarę podobieństwa wektorów postaci drgań własnych założonych i uzyskanych wprowadzono stosunki kolejnych współrzędnych odpowiadających sobie wektorów własnych $\varphi_{i}^{*}$ oraz $\varphi_{i}$. Dla kolejnych wariantów stosunki współrzędnych odpowiadających sobie wektorów własnych zapisano W postaci macierzy $\Psi_{A 1}, \Psi_{A 2}, \Psi_{B 1}$ oraz $\Psi_{B 2}$ :

$$
\begin{aligned}
\Psi_{A 1} & =\left[\begin{array}{lllll}
1,082 & 1,116 & 1,149 & 0,994 & 1,149 \\
1,089 & 1,203 & 1,317 & 1,131 & 1,054 \\
1,074 & 1,255 & 1,041 & 0,997 & 1,183 \\
1,089 & 0,927 & 0,980 & 1,083 & 1,077 \\
1,090 & 1,139 & 1,063 & 1,039 & 0,830
\end{array}\right] \\
\boldsymbol{\Psi}_{B 1} & =\left[\begin{array}{lllll}
1,083 & 1,247 & 1,168 & 1,033 & 1,287 \\
1,087 & 1,361 & 1,312 & 1,212 & 1,123 \\
1,077 & 0,856 & 1,098 & 1,021 & 1,149 \\
1,110 & 0,826 & 1,222 & 0,974 & 0,981 \\
1,158 & 1,053 & 1,023 & 1,038 & 0,915
\end{array}\right] \\
\boldsymbol{\Psi}_{A 2} & =\left[\begin{array}{lllll}
1,037 & 1,030 & 1,127 & 1,232 & 1,902 \\
1,042 & 1,393 & 0,817 & 1,035 & 0,985 \\
1,033 & 1,275 & 1,125 & 1,002 & 0,985 \\
1,034 & 0,933 & 1,250 & 1,018 & 1,162 \\
1,063 & 1,076 & 0,945 & 0,947 & 0,974
\end{array}\right] \\
\boldsymbol{\Psi}_{B 2} & =\left[\begin{array}{lllll}
1,120 & 1,124 & 1,230 & 1,132 & -1,63 \\
1,149 & -6,40 & 1,217 & 1,056 & 0,729 \\
1,071 & -0,29 & 1,013 & 1,669 & 1,617 \\
1,040 & 0,728 & -0,46 & 1,076 & 6,036 \\
0,974 & 2,371 & 1,181 & 0,946 & 0,530
\end{array}\right]
\end{aligned}
$$

\section{Podsumowanie}

W artykule zastosowano metodę algorytmów genetycznych do rozwiązania odwrotnego zagadnienia własnego jako zadania wyznaczenia macierzy mas i macierzy sztywności dla zadanego wektora częstotliwości drgań własnych oraz zadanej macierzy postaci drgań własnych dla dyskretnego modelu o pięciu stopniach swobody.

Przyjęto 16-elementowy chromosom, którego geny w postaci wartości zmiennoprzecinkowych reprezentują parametry masowe i sztywnościowe układu.

Analizę numeryczną przeprowadzono dla dwóch wariantów funkcji przystosowania oraz dla dwóch zestawów operatorów selekcji i krzyżowania.

$\mathrm{Na}$ podstawie wyników zebranych w postaci numerycznej (w tabelach) i graficznej (na rysunkach), wybrano najkorzystniejszy wariant obliczeniowy (tzn.wariant $\mathrm{A}_{1}$ ), w którym funkcja przystosowania jest związana $\mathrm{z}$ minimalizacją błędu średniokwadratowego częstotliwości drgań własnych i postaci drgań własnych; operację selekcji przeprowadzono za pomocą selekcji według rozkładu stochastycznego, a do operacji krzyżowania zastosowano krzyżowanie binarne.

Analiza wyników przeprowadzonych badań numerycznych wskazuje na praktyczne aspekty zastosowania algorytmów genetycznych $\mathrm{w}$ procesach syntezy $\mathrm{i}$ identyfikacji dyskretnych modeli układów nośnych pojazdów.

Celem dalszych badań będzie opracowanie metodyki tworzenia i wyboru funkcji przystosowania oraz określenie zasad wyboru problemowo zorientowanych operatorów algorytmu genetycznego w zastosowaniu do zadania projektowego o większym wymiarze.

\section{Literatura}

[1] Alkhatib R., Nakhaie Jazar G., Golnaraghi M. F., Optimal design of passive linear suspension using genetic algorithm, Journal of Sound and Vibration, Vol. 275, 2004.

[2] Chu M. T., Inverse Eigenvalue Problems, SIAM REV, Vol. 40, No. 1, 1998.

[3] Esat I., Bahai H., Vibratory System Synthesis for Multi-body Systems Based on Genetic Algorithm, Journal of Sound and Vibration, Vol. 230(4), 2000.

[4] Gladwell G. M., Inverse finite element vibration problems, Journal of Sound and Vibration, Vol. 211(2), 1999.

[5] Gladwell G. M., Inverse problems in vibration - II, Appl Mech Rev, Vol 49, no 10, part 2, 1996.

[6] Pieczara J., Algorytmy genetyczne $w$ mechanice konstrukcji, Rozprawy Monografie 134, Wydawnictwa AGH, Kraków 2004.

[7] Sivan D. D., Ram Y. M., Optimal Construction of a Mass-Spring System with Prescribed Modal and Spectral Data, Journal of Sound and Vibration, Vol. 201(3), 1997.

[8] MATLAB, wersja 7.0.4. 